\title{
Применение норм международного права арбитражными судами Российской Федерации*
}

Зимненко Б. Л.**

Конституция Российской Федерации включила общепризнанные принципы и нормы международного права и международные договоры страны в ее правовую систему (п. 4 ст. 15). Данное положение означает, что правоохранительные органы, в том числе суды, в своей деятельности обязаны руководствоваться не только внутритосударственными, но и международно-правовыми нормами. Согласно ст. 3 Федерального конституционного закона "О судебной системе Российской Федерации" ее единство обеспечивается применением всеми судами общепризнанных принципов и норм международного права и международных договоров Российской Федерации.

В настоящей статье анализируется практика применения общепризнанных и договорных норм международного права арбитражными судами Российской Федерации.

Но не каждый международный договор Российской Федерации признается частью правовой системы нашей страны. В силу п. 3 ст. 5 Федерального закона "О международных договорах Российской Федерации" "положения официально опубликованных международных договоров Российской Федерации, не требующие издания внутригосударственных актов для применения, действуют в Российской Федерации непосредственно. Для осуществления иных положений международных договоров Российской Федерации принимаются соответствующие правовые акты".

Следовательно, частью правовой системы России признается международный договор России, который одновременно соответствует следующим требованиям: он должен быть заключен в письменной форме; вступить в силу и стать обязательным для Российской Федерации; его положения должны быть четкими и конкретными,

\footnotetext{
* В настоящей статье речь идет не о третейских (арбитражных) судах, к примеру, Международном коммерческом арбитражном суде при Торгово-промышленной палате Российской Федерации, а о федеральных арбитражньх судах Российской Федерации и практике применения ими норм международного права.

** Знмненко Богдан Леонидович - к.ю.н., адвосат Московской городской коллегии адвокатов.
} 
способными оказывать регулирующее воздействие на отношения с участием субъектов национального права (самоисполнимые международные договоры); он официально опубликован в соответствии с действующим российским законодательством.

Из ст. 118 и 127 Конституции следует, что арбитражные суды страны, возглавляемые Высшим Арбитражным Судом Российской Федерации, осуществляют судебную власть при разрешении споров, возникающих из гражданских правоотношений (экономических споров), а также из правоотношений в области управления в процессе реализации предпринимательской и иной экономической деятельности.

Арбитражно-процессуальный кодекс Российской Федерации (далее - АПК РФ) предусматривает, что арбитражные суды применяют международные договоры, содержащие как материальные, так и процессуальные нормы. Если международным договором Российской Федерации установлены иные правила, чем предусмотренные законом, то согласно п. 3 ст. 11 АПК РФ применяются правила международного договора. В силу ст. 3 АПК РФ "если международным договором Российской Федерации установлены иные правила судопронзводства, чем те, которые предусмотрены законодательством Российской Федерации, то применяются правила международного договора"1.

Анализ сложившейся судебно-арбитражной практики применения норм международного права позволяет сформулировать ряд основных закономерностей.

Арбитражные суды в своей деятельности исходят из того, что нормы международного права по отношению к законодательным актам носят специальный характер, что позволяет им отменять закон, противоречащий международному договору².

1 Собрание законодательства РФ, 1995, № 19, ст. 1709.

2 Понятие "отмены" носит как относительный, так и абсолютный характер. Если регулирующее воздействие договора направлено на международные отношения негосударственного характера (отношения с "нностранным элементом"), то его правила необходимо рассматривать как специальную норму, а правила закона - как общую. В силу общего принципа права спецнальная норма отменяет общую: lex specialis derogat lex generalis. Здесь можно говорить об относительной "отмене". Но если участкики международного договора решили распространить регулирующие свойства такого соглашения, на внутригосударственные отношения, договор в этой ситуации отменяет закон, который не подлежит применению в дальнейшем ни при каких условиях. В этом случае имеется в виду абсолютная "отмена". 
Белорусское акционерное общество обратилось в суд с иском о взыскании с российского общества с ограниченной ответственностью (ООО) задолженности и неустойки по договору поставки. Рассматривая данное дело, арбитражный суд указал, что поскольку "стороны не определили в контракте, законодательство какого государства применимо к их отношениям, обусловленным исполнением договора поставки, суд этот вопрос решает самостоятельно на основе п. "е" ст. 11 Соглашения "О порядке разрешения споров, связанных с осуществлением хозяйственной деятельности", предусматривающего, что "права и обязанности сторон по сделке определяются по законодательству места ее совершения". В силу совершения сделки в Москве судебный спор разрешается на основе российского законодательства ${ }^{3}$.

Если бы суд согласился на коллизионную норму, содержащуюся в ст. 166 Основ гражданского законодательства Союза ССР (действующих в настоящее время), то применимым правом к отношениям сторон было бы законодательство Белоруссии, так как предприятиепоставщик находилось на территории этой республики.

Специальный характер содержащихся в международном договоре норм, обусловливает вывод о том, что вопросы, не урегулированные международным договором, разрешаются на основе российского законодательства.

Федеральный Арбитражный суд Московского округа, рассматривая в кассационном порядке иск швейцарской компании "SisnoTrading" к российскому АО "Носта" о взыскании суммы основной задолженности, в постановлении отметил, что "к вопросам, не урегулированным Венской конвенцией международной купли-продажи товаров 1980 года, применяются положения национального права"4. Высший Арбитражный Суд РФ в информационном письме от 16 февраля 1998 г. также обратил внимание на то, что если "спорные вопросы не урегулированы международным договором, суд применяет нормы внутригосударственного российского гражданского права, в том числе Гражданского кодекса Российской Федерации"5.

Арбитражные суды при рассмотрении дел с "иностранным элементом", как правило, обрашаются к международным договорам

3 Информационное письмо Президиума Высшего Арбитражного Суда РФ от 16 февраля 1998 г., Вестник ВАС РФ. 1998, № 4. С. 38-56.

4 Дело не опубликовано. См. архив Арбитражного суда Москвы.

5 Вестник ВАС РФ. 1998, № 4. С. 48. 
Российской Федерации, которые могут содержать иные правила, чем предусмотренные внутригосударственным законодательством.

Высший Арбитражный Суд РФ при подготовке обзора судебной практики указал что согласно ст. 55 Консульского устава все документы, исходящие от властей иностранного государства, подлежат консульской легализации. Исключение из этого правила может предусмотреть только международный договор. Так, двусторонний договор о правовой помощи между Российской Федерацией и Китайской Народной Республикой 1992 года установил, что официальные документы, составленные на территории одной договаривающейся стороны, пользуются доказательной силой официальных документов на территории другой договаривающейся стороны без легализации при наличии подписи и официальной печати"6.

При рассмотрении другого дела арбитражный суд пытался проанализировать существующие международные соглашения, которые устанавливали бы специальные правила, однако, в связи с их отсутствием суд применил общее правило, содержащееся в национальном законодательстве.

Фирма "Наим Анвар Ко. Лтд." (Афганистан, Кабул) обратилась в -арбитражный суд Москвы с иском к ОАО "Внешинторг" о признании недействительным протокола общего собрания его акционеров. Арбитражный суд Москвы 25 августа 1997 г. исковые требования удовлетворил частично. Постановлением апелляционной инстанции от 16 декабря 1997 г. решение отменено, иск оставлен без рассмотрения в связи с тем, что лицо, подписавшее исковое заявление, не обладало такими полномочиями. Федеральный арбитражный суд Московского округа постановление апелляционной инстанции отменил и дело передал на рассмотрение в ту же инстанцию Арбитражного суда г. Москвы. Постановлением апелляционной инстанции 17 марта $1998 \mathrm{r}$. решение суда от 25 августа 1997 г. оставлено без изменения.

В постановлении от 8 сентября 1998 г. Президиум Высшего Арбитражного Суда Российской Федерации, оставляя в силе постановление апелляционной инстанции от 16 декабря 1997 г., подчеркнул, что фирма, заявившая исковые требования и называющая себя юридическим лицом Исламского государства Афганистан, в подтверждение своего юридического статуса представила документы, заверенные консульской службой посольства Исламского государства Афганистан в Российской Федерации.

6 Там же. 1997, № 3. С. 92-93. 
Однако арбитражные суды принимают в качестве доказательств иностранные официальные документы при условии их легализации консульскими службами Российской Федерации. Международные договоры между Россией и Афганистаном, в том числе Консульская конвенция между СССР и ДРА от 24 мая 1981 г., консульскую легализацию не отменяют. Следовательно, при отсутствии на иностранных официальных документах отметки о их легализации российскими дипломатическими или консульскими службами их согласно ст. 57 АПК РФ нельзя считать допустимыми доказательствами по делу и подтверждать ими правовой статус иностранного лица в деле?.

Акционерное общество "Центрозап" (Республика Польша) обратилось в Арбитражный суд Челябинской области с иском о признании недействительным решения Государственной налоговой инспекции по г. Магнитогорску о взыскании с него 127612632 руб. Решением суда исковые требования удовлетворены частично. Постановлением апелляционной инстанции решение оставлено без изменения. Федеральный арбитражный суд Уральского округа решение и постановление отменил, исковые требования удовлетворил в полном объеме. В постановлении от 20 апреля 1999 г. по делу № 4419/98 Президиум Высшего Арбитражного Суда обратил внимание на то, что Соглашение между Правительством Российской Федерации и Правительством Республики Польша об избежании двойного налогообложения доходов и имущества от 22 мая 1992 г., вступившее в силу 23 февраля 1993 г., не касается вопросов обложения косвенными налогами. Следовательно, у арбитражного суда имелись основания рассматривать истца плательщиком налога на добавленную стоимость и специального налога, поскольку международными соглашениями не установлено иное (курсив мой - Б.3. $)^{8}$.

Следовательно, при отсутствии соответствующих международных соглашений, устанавливаюших иные правила, чем закон, арбитражный суд руководствуется общими правилами, сформулированными в национальном законодательстве.

Нельзя не обратить внимание еше на один аспект взаимодействия международного права и национального законодательства, который

7 Вестник Высшего Арбитражного Суда РФ. 1998, № 12. С. 53.

8 Постановление Высшего Арбитражного Суда не опубликовано. См. архив арбитражного суда Челябинской области.

${ }^{9}$ Ведомости Съезда Народных Депутатов РФ и Верховного Совета РФ. 1993, № 31, ст. 1224. 
Высший Арбитражный Суд Российской Федерации отметил в одном из своих информационных писем.

Как следует из ст. 181 Таможенного кодекса РФ, осуществление производственной и иной коммерческой деятельности, перемещение товаров, транспортных средств через таможенную границу допускается только с разрешения таможенных органов Российской Федерации и под их контролем, за исключением случаев, предусмотренных законодательными актами Российской Федерациия. Однако Высший Арбитражный Суд РФ в обзоре практики рассмотрения споров, связанных с применением таможенного законодательства, отметил, что "исключение из данного правила (ст. 181 Таможенного кодекса РФ) составляют случаи, когда такое перемешение возможно и (курсив мой - Б.3.) в соответствии с нормами международного права"10.

Таким образом, Высший Арбитражный Суд, принимая во внимание смысл и дух п. 4 ст. 15 Конституции Российской Федерации, допускает, что международные договоры и общепризнанные нормы международного права могут предусматривать исключения из правил, установленных законом, даже если он о такой возможности прямо не упомннает.

- Как уже отмечалось выше, создаваемые международно-правовые нормы должны единообразно применяться в государствах. Поэтому и применять их, и толковать следует в том смысле и порядке, который существует в международном праве, а также с учетом международной практики их применения.

Высший Арбитражный Суд Российской Федерации отметил: "Суд, применяя нормы международных договоров, руководствуется тем, что толкование международных правил производится в порядке, определенном разд. 3 ч. 3 Венской конвенции о праве международных договоров от 23 мая 1969 г. Суд толкует международно-правовую норму добросовестно, в контексте и в соответствии с объемом и целями международного договора Российской Федерации"11. Как свидетельствует практика, арбитражные суды учитывают связь норм международного права с международной нормативной системой.

Фирма, зарегистрированная в иностранном государстве, обратилась в арбитражный суд с иском к российскому акционерному обществу о возмещении убытков. При рассмотрении указанного дела ар-

10 Закон. 1997, № 9. С. 97-102.

11 Вестник ВАС РФ. 1999, № 8. С. 6. 
битражный суд, приняв во внимание заявление СССР при присоединении к Конвенции о договорах международной купли-продажи товаров 1980 года, отметил, что "в ходе судебного разбирательства было установлено, что к отношениям сторон применима Венская конвенция о договорах международной купли-продажи товаров 1980 года. Конвенция содержит норму императивного характера о форме сделки (ст. 12). При этом в указанной статье оговаривается обязательность письменной формы сделки. Это правило распространяется как на международный договор купли-продажи, так и на его изменение (ст. 29 Конвенции). Статья 12 Конвенции применяется, когда хотя бы одна из сторон в договоре имеет коммерческое предприятие в государстве-участнике Конвенции, законодательство которого требует, чтобы договоры купли-продажи заключались в письменном виде, о чем это государство сделало заявление на основании ст. 96 Конвенции. СССР в результате присоединения к Конвенции заявил о соблюдении требований ст. 12. Статья 13 Конвенции к письменной форме (из электронных видов связи) относит только сообщения "по телеграфу и телетайпу". Таким образом, договор купли-продажи и его изменение в случае участия в нем фирмы из Российской Федерации должны заключаться в письменной форме, каковой телефонная связь не является" 12 .

Следовательно, приняв во внимание заявление СССР в ходе присоединения к Конвенции, российский арбитражный суд надлежащим образом применил и истолковал нормы международного права.

Как было отмечено выше, применению подлежат международные договоры РФ только в том случае, когда они вступили в силу для Российской Федерации. Указанное положение находит подтверждение в судебной практике.

Арбитражный суд из-за неподведомственности ему спора, прекратил дело по иску российской организации к иностранной фирме, сославшись на то, что иностранное государство, на территории которого она находится, подписало международный договор с Российской Федерацией, требовавший в дальнейшем его ратификации. На момент рассмотрения дела договор не был ратифицирован. В ходе судебного рассмотрения спора в кассационном порядке Федеральный арбитражный суд округа отметил, что "поскольку нератификация международного договора иностранным государством не может

12 Там же. 1998, № 4. С. 38-56. 
рассматриваться как запрещение на рассмотрение таких споров в арбитражных судах Российской Федерации, то решение суда первой инстанции незаконно. Иными словами, международный договор не вступил в международную силу и, следовательно, не порождает соответствующих прав и обязанностей"13.

Согласно Конституции Российской Федерации международные договоры и общепризнанные принципы и нормы международного права - неотьемлемая часть правовой системы Россин. При этом основной закон страны умалчивает о возможности применения общепризнанных принципов и норм международного права. В статье, посвященной нормативным актам, применяемым арбитражными судами при осуществлении правосудия, АПК РФ упоминает исключительно международные договоры страны. Но судебно-арбитражная практика свидетельствует, что суды применяют не только международные договорные нормы, но и общепрнзнанные нормы международного права ${ }^{14}$. Как известно, содержание общепризнанной нормы

13 Хозяйство и право. 1997, № 7.

В соответствии с п. 6 ст. 22 АПК РФ "арбитражный суд рассматривает подведомственные ему дела с участием организаций и граждан Российской Федерацин, а также иностранных организаций, организаций с иностранными инвестициями, международных организаций, иностранных граждан, лиц без гражданства, осуществляющих предпринимательскую деятельность, если иное не предусмотрено международным договором Российской Федерации (курсив мой Б.3.)" (Собрание законодательства Российской Федерашии. 1995, № 19, ст. 1709).

14 Арбитражные суды очень часто применяют международные правила толкования торговых терминов ИНКОТЕРМС-90, разработанные Международной торговой палатой (см., к примеру, Информационное письмо Высшего Арбитражного Суда РФ № 29; Вестник ВАС РФ, 1998, № 4; Вестник ВАС РФ, 1997, № 6). Как справедливо отмечает судья Высшего Арбитражного Суда РФ, профессор Т. Н. Нешатаева, природа этих правил - обычаи делового оборота в сфере международной торговли. Действующее российское гражданское законодательство предусматривает, что обычай делового оборота наряду с законодательством может регулировать отношения между сторонами внешнеэкономическото контракта (ст. 6 ГК РФ) (Т.Н. Нешатаева. Иностранные предприниматели в России. Судебно-арбитражная практика. С. 37-42). В связи с этим необходимо различать общепрнзнанные нормы международного права, которые в силу п. 4 ст. 15 Конституции являются частью правовой системы России, и международные правила толкования торговых терминов как обычан делового оборота, регулируюшие отношения искпючительно между коммерческими предприятиями в сфере внешней торговл. Позтому в настоящей работе не затрагиваются особенности применения, к примеру, правил ИНКОТЕРМС - 90 в арбитражньх судах, так как они не признаются нормами международного публнчного права. 
международного права может раскрываться в различных международных документах, включающих резолюции международных организаций, проекты международных соглашений и т.д. ${ }^{15}$

При рассмотрении дела арбитражный суд применил общепризнанную норму, содержащуюся в Конвенции ООН о независимых гарантиях и резервных аккредитивах от 26 января 1996 г., рекомендованной Генеральной Ассамблеей ООН к подписанию. Согласно этой норме недобросовестное требование бенефициара о платеже по международному гарантийному обязательству в случае, когда оно исполнено удовлетворительным для него образом, может являться формой злоупотребления правом и служить добросовестному гаранту основанием к приостановлению платежа до принятия судебных мер. Руководствуясь указанным положением, а также ст. 10 ГК РФ, арбитражный суд отказал бенефициару в удовлетворении его исковых требований к гаранту 16 .

В соответствии с п. 4 ст. 158, ст. 176 АПК РФ основаниями к изменению (отмене) решения (постановления) арбитражного суда признается нарушение или неправильное применение норм материального или процессуального права. Судебная практика свидетельствует, что нарушение арбитражным судом процессуальных или материальных норм международного права также влечет изменение или отмену судебного акта.

Фирма "Цинекс" (Австрия, Вена) обратилась в Арбитражный суд Москвы с иском к акционерному обществу отрытого типа "Центр международной торговли и научно-технических связей с зарубежными странами" (Москва) о взыскании суммы процентов за пользование кредитом и штрафа за несвоевременный возврат кредита. Суд, сославшись на пропуск исковой давности, удовлетворил требования истца частично.

Федеральный арбитражный суд Московского округа решение изменил, исходя из того, что между сторонами возникли кредитные отношения в виде отсрочки платежа за работы, выполненные по контракту. В протесте заместителя Председателя Высшего Арбитражного Суда Российской Федерации предлагалось состоявшиеся судебные акты отменить и дело передать на новое рассмотрение. Разделяя

15 Подробнее см. Г. М. Даниленко. Обычай в современном международном праве. М., Наука, 1988.

16 Вестник ВАС РФ. 1998, № 4. С. 41-42. 
доводы протеста, Высший Арбитражный Суд указал, что "порядок представления процессуальных документов, идентифицируюших личность иностранного юридического лица, установлен Конвенцией по вопросам гражданского процесса от 1 марта 1954 г. и Конвенцией, отменяющей требования легализации иностранных официальных документов 1961 года. По настоящему делу такой порядок соблюден не был. Учитывая вышеизложенное, судебные акты подлежат отмене"17.

Открытое акционерное общество "Норд-Вест Ф.К." обратилось в Aрбитражный суд Мурманской области с иском к фирме "INTERCARGO DANMARK A/S" о взыскании убытков. Определением от 3 июня 1998 г. суд отказал в принятии искового заявления. Апелляционная инстанция оставила в силе указанное определение. Удовлетворяя протест заместителя Председателя Высшего Арбитражного Суда Российской Федерации, Президиум Высшего Арбитражного Суда РФ подчеркнул: "Суд не учел, что в основе спора лежат отношения по международной дорожной перевозке грузов, следовательно, к отношениям сторон подлежит применению Женевская конвенция от 19 мая 1956 г. о договоре международной перевозке грузов. Статья 31 Конвенции предусматривает, что по всем спорам, возникающим из перевозки, подпадающей под действие настоящей Конвенции, истец, кроме согласованных сторонами судов стран-участниц Конвенции, может обратиться в суд страны, на территории которой находится место принятия груза к перевозке. При таких обстоятельствах судебные акты, противоречащие международным договорам Российской Федерации, подлежат отмене"18.

Белорусское предприятие обратилось в Арбитражный суд Москвы с иском к российскому акционерному обществу о признании договора купли-продажи акции недействительным. Решением суда в удовлетворении исковых требований было отказано. Апелляционная инстанция оставила решение без изменения. В постановлении от 22 февраля 1999 г. Федеральный арбитражный суд Московского округа по данному делу отметил: "Суд не определил согласно белорусскому законодательству правоспособность истца, не являющегося российским юридическим лицом. В соответствии со ст. 11 "а" Соглашения о порядке разрешения споров, связанных с осушествлением хо-

17 Там же. 1996, № 12. С. 101-102.

18 Вестник ВАС РФ. 1999, № 11. С. 50-51. 
зяйственной деятельности, подписанного правительствами государств-участников СНГ 20 марта 1992 г. в Киеве, гражданская правоспособность и дееспособность юридических лиц и предпринимателей определяется по законодательству государства-участника СНГ, на территории которого учреждено юридическое лицо"19. Следовательно, неприменение судом международного договора обусловило вынесение незаконного и необоснованного решения, что повлекло его безусловную отмену.

В постановлении от 11 апреля 2000 г. по делу, касаюшемуся признания недействительным решения Госналогинспекции по г. Казани, Высший Арбитражный Суд Российской Федерации отметил, что Суд не оценил подзаконный акт и его соответствие законодательству, не исследовал вопросы, связанные с обязанностью иностранных юридических лиц по уплате налогов на территории Российской Федерации, и соответственно обязанности налогового агента по их удержанию с учетом международных обязательств 20 .

В постановлении от 25 апреля 2000 г. по делу о признании частично недействительным решения Госналогинспекции по г. Находка Высший Арбитражный Суд Российской Федерации, отменяя решение и постановление Арбитражного суда Приморского края, также указал, что "суд не оценил правильности применения налоговым органом подзаконного акта, соответствия его законодательству, положениям международного договора"21. Таким образом, неприменение судом международного договора Российской Федерации обусловило отмену соответствующего судебного акта.

19 Указанное дело опубликовано не было (Дело № А40-30496/98-27-373). См. архив арбитражного суда города Москвы.

20 Вестник ВАС РФ. № 7, 2000. С. 9.

21 Вестник ВАС РФ. № 8, 2000. С. 7. 